\title{
New evidence for a mid to late-Holocene change in the marine reservoir effect across the South Pacific Gyre \\ Fiona Petchey ${ }^{1,2}$
}

1. Radiocarbon Dating Laboratory, Faculty of Science and Engineering, University of Waikato, New Zealand.

2. ARC Centre of Excellence for Australian Biodiversity and Heritage, College of Arts, Society and Education, James Cook University, Cairns, QLD, Australia.

E-mail: fpetchey@waikato.ac.nz

\begin{abstract}
Holocene climate change in the South Pacific is of major interest to archaeologists and Quaternary researchers. Regional surface ocean radiocarbon $\left({ }^{14} \mathrm{C}\right)$ values are an established proxy for studying changing oceanographic and climatic conditions. Unfortunately, radiocarbon variability in the marine environment over the period of specific importance to human colonization of the remote Pacific islands - the last 3500 years - has been poorly studied. In order to build robust and accurate archaeological chronologies using shell, it is important to rectify this. In this paper, radiocarbon marine reservoir offsets $(\Delta R)$ are presented from eight archaeological sites, ranging in age from $350 \mathrm{cal} \mathrm{BP}$ to $3000 \mathrm{cal} \mathrm{BP}$, and compared to coral datasets from the east Australian coastline. The results indicate that a significant decrease in the South Pacific Gyre $\Delta R$ occurred between 2600 and 2250 cal BP most likely caused by changes in ocean circulation and climate. Accurately recording the timing of variability in reservoir offset is critical to untangling changes in society that took place in the Pacific, in particular, the development of Ancestral Polynesian Society.
\end{abstract}

\section{INTRODUCTION}

The marine reservoir age " $R$ " is the offset in ${ }^{14} \mathrm{C}$ age between the atmosphere and the global with regional offsets from $R$ termed the local marine reservoir age or $\Delta R$ ocean (Stuiver et al. 1986). Calibration of marine ${ }^{14} \mathrm{C}$ dates involves application of a $\Delta R$ to the marine calibration curve (Marine13; Reimer et al. 2013) to account for these regional offsets. A $\Delta R$ can be calculated from "paired" (contemporaneous) terrestrial and marine samples excavated from archaeological sites or from isochrones such as tephra deposited offshore (e.g., Sikes et al. 2000). A regional reservoir offset can also be calculated from known-age shells or coral collected prior to atmospheric bomb testing (e.g., Petchey et al. 2008b), or from samples where independently measured calendar ages can be obtained, such as U/Th, ${ }^{14} \mathrm{C}$ pairs (e.g., Clark et al. 2016a). No matter what materials are used for determining the $\Delta R$, they must comply with a set of prerequisites (see Petchey et al. 2009). For archaeological shell samples, the age is determined by dating short-lived - identified to species and/or element - "paired" charcoal from contemporaneous contexts.

In the modern Pacific Ocean, a gradient exists between older reservoir ages in the tropical east, and younger ages in subtropical regions and the tropical west, which reflect the surface flow of the South Equatorial Current (SEC) (Burr et al. 2009; Petchey et al. 2008a) (Figure 1). This gradient is indicative of the upwelling of older ${ }^{14} \mathrm{C}$-depleted waters in the east (Toggweiler et al. 1991; Ortlieb et al. 2011), the subsequent modification of the water by air-sea exchange, and a deepening thermocline as this water flows westward across the Pacific. Traditionally, $R$ and $\Delta R$ for any given location have been assumed to be broadly constant over time (Stuiver et al. 1986). However, as more information becomes available this assumption does not hold up to scrutiny. Abrupt shifts have been recorded in early to mid-Holocene samples across the South Pacific (e.g., Hua et al. 2015, Ortlieb et al. 2011, Yu et al. 2010; Fairbanks et al. 2005; Paterne et al. 2004). Possible causes for these temporal reservoir changes, include a change in ${ }^{14} \mathrm{C}$ content and frequency of upwelled waters in the eastern tropical Pacific, as well as variation in ocean circulation associated with La Niña/El Niño conditions, intensity of easterly trade winds, and movement of the Inter-tropical Convergence Zone (ITCZ) and the associated South Pacific Convergence Zone (SPCZ) - where northern and southern air masses converge and control the spread of these upwelled waters to western regions (Hua et al. 2015) ${ }^{1}$.

Most research on this subject has concentrated on the early to mid-Holocene, with little work investigating change over the last 3500 years; the period of human settlement of the South Pacific (Kirch 1997; Kirch and Green 2001). Moreover, only 16 data points were reported in the references given above over this time period, and no values from central/western Pacific archaeological sources were considered. This is because reliable $\Delta R$ from archaeological sites has been limited by material availability and inherent problems with site

\footnotetext{
1 During La Niña events, the SPCZ moves south-westward and limits old salty waters from the east reaching the western Pacific sites. In contrast, during El Niño events, the SPCZ moves north-eastward and the SEC strengthens, allowing more of these older waters to spread to the west (Hua et al. 2015:41).
} 
disturbance (cf. Petchey et al. 2018, Clark et al. 2016b, Ortlieb et al. 2011), but also reflects disproportionate levels of funding for broad-scale paleoenvironmental research over archaeological interests. One study specifically designed to investigate the issue of change was undertaken by Petchey et al. (2009). Using "paired" terrestrial/marine samples from a range of archaeological sites, they noted little change in $\Delta R$ over the last 750 years for American Sāmoa (dated to c. 600 cal BP), southern Cook Islands (c. 670 cal BP), and the Marquesas Islands (c. 380 and 670 cal BP). Generally, however, archaeological dating in this region has had to largely rely on $\Delta R$ values calculated from modern (pre-AD 1950) validation studies (e.g., Petchey et al. 2008, Phelan 1999). A clever solution to overcoming the issue of disjunction between the terrestrial and marine values was reported by Clark et al. (2016a) using U/Th, ${ }^{14} \mathrm{C}$ pairs on archaeologically derived Acropora spp. coral branches from Ofu Island, American Sāmoa, dated to c. 2300 cal BP. The negative $\Delta R$-value obtained $\left(-101 \pm 72{ }^{14} \mathrm{C}\right.$ years $)$ was interpreted as possibly being caused by spatial and/or temporal changes to the marine environment.

More recently, information for this period of interest has become available from a sequence of paired $\mathrm{U} / \mathrm{Th},{ }^{14} \mathrm{C}$ dates from black coral collected from the southeastern coast of Australia (Komugabe-Dixson et al. 2016). Komugabe-Dixson et al. (2016:976-978) noted two distinct intervals when $\Delta R$ was significantly lower; between 4000 and $3300 \mathrm{cal} \mathrm{BP}\left(\Delta R=-132 \pm 79{ }^{14} \mathrm{C}\right.$ years $)$ and between 2700 to $1900 \mathrm{cal} \mathrm{BP}\left(\Delta R=-156 \pm 79{ }^{14} \mathrm{C}\right.$ years). They attributed these negative values to increased penetration of well-ventilated gyre waters southward into the South Tasman Sea in response to strong and abrupt El Niño events that reduced upwelling in the southeast Pacific (as recorded by Ortlieb et al. 2011) and displaced the salinity front that separates fresher Western Pacific Warm Pool water from saltier and cooler waters in the east, enabling increased westward flow of gyre waters into the Tasman Sea. Interconnectivity between western and eastern sides of the South Pacific (Figure 1) means that significant reservoir changes should be expected in the central gyre as well and, therefore, adds further doubt to the validity of using a constant $\Delta R$-value to calibrate marine shell ${ }^{14} \mathrm{C}$ dates from this region.

Held within the archaeological literature are a host of shell/charcoal ${ }^{14} \mathrm{C}$ pairs which can assist with this problem. Unfortunately, the interpretation of marine shell ${ }^{14} \mathrm{C}$ dates has been complicated by diet and habitat differences that rarely reflect open marine conditions. Research along the southern coast of Papua New Guinea at Caution Bay (Petchey et al. 2012, 2013) identified species-specific $\Delta R$ variation of up to $360{ }^{14} \mathrm{C}$ years in deposits dated to 2000-2150 cal BP. They attributed this to the possible incorporation of carbon from limestone in the hinterland but also observed that the magnitude of variation depended on the taxa dated. More recent research into shell taxa variation (Petchey et al. 2018) has provided methods to cull unreliable shell samples using $\delta^{13} \mathrm{C}$ and $\delta^{18} \mathrm{O}$ to help identify carbon source. This has been successful in identifying estuarine-specific signals in some bivalves and, in areas where water has percolated through limestone, can help identify shells that are influenced by ${ }^{14}$ C-depleted hardwater (Petchey and Clark 2011; Petchey et al. 2018). This work, combined with archaeological $\Delta R$ values reported in the literature, has enabled the reinvestigation of change in $\Delta R$ over time in the central Pacific Gyre region presented below.

\section{METHOD}

For this evaluation, sample pairs from published archaeological sources and from unpublished $\Delta R$ research by the author have been collated. All radiocarbon and stable isotope information is given in Table 1 . Additional constraints to the archaeological dataset have been applied, as outlined below:

1. Region: The region of interest is encircled by the South Pacific Subtropical Gyre, a circulatory system driven by the combined effects of the tropical trade winds and westerly winds in the subtropical regions, the combined results of which are the high-latitude eastward-flowing Antarctic Circumpolar Current (ACC) and the mid-latitude westward-flowing South Equatorial Current (SEC). The SEC transports water from the gyre center and bifurcates on the east coast of Australia, feeding both the East Australian Current (EAC) and the New Guinea Coastal Current (NGCC) (Figure 1). This circulatory system is considered to create relatively stable surface conditions at the center of the gyre (Rougerie and Wauty 1993) but upwelling and mixing of water occur at the edge of the gyre and where large island chains disturb the flow of surface waters (Petchey et al. 2008). Consequently, we have avoided $\Delta R$ values from island locations at the edge of the gyre. This includes the Solomon Islands (Petchey et al. 2004, 2008a), Papua New Guinea (Petchey et al. 2012, 2013), Norfolk and Kermadec Islands, New Zealand and the Chatham Islands (Petchey et al. 2008b).

2. Shell taxa: Most shellfish precipitate their shells in equilibrium with the isotopic signature of dissolved inorganic carbon from the waters they live in (McConnaughey et al. 1997). This can, however, be complicated by dietary and habitat preferences of the animal studied. Many gastropods directly ingest sediment via algal grazing or by direct ingestion of the sediment. Therefore, ${ }^{14} \mathrm{C}$ results from algal grazing or herbivorous gastropods are only included if the island group in question is volcanic. In limestone locations, such as Tongatapu Island, only those bivalves with $\delta^{13} \mathrm{C}$ values equivalent too, or higher than, 
the modern ocean average (c. 1.7\%o) are selected (cf., Petchey et al. 2018). This minimizes the likelihood of incorporating bicarbonate ions that incorporate ancient carbon from the calcareous strata.

3. Context: We have not considered any archaeological $\Delta R$ values calculated using Bayesian methodologies (e.g., Macario et al. 2015). Such methods enable the $\Delta R$ to be calculated from archaeological evidence that is temporally constrained despite strict contemporaneity being unknown (Petchey et al. 2004; Jones et al. 2007). Few archaeological chronologies in the South Pacific have been constructed with sufficient numbers of stratigraphically secure dates to achieve sufficiently precise results using this approach (see however Petchey et al. [2015] who use this methodology for gastropod shells from the limestone island of Efate, Vanuatu).

Archaeological samples (Figure 1, Table 1)

American Sāmoa (Manu'a Group): Three $\Delta R$ values on U/Th dated corals (Acropora spp.) have been identified from pre-2300 cal BP archaeological deposits on Va'oto, Ofu Island (Clark et al. 2016a). Two of the corals come from pre-colonization contexts and are unmodified, while the third has been used as an abrader. Although mixing of the cultural deposit is likely (a second unmodified coral fragment from the exact same context as sample 201422 [2375 \pm 11 cal BP] gave a different age [i.e., sample 2014-23; $2503 \pm 7$ cal BP; Clark et al. 2016b:270]), the use of U/Th to obtain a calendar age on the same ${ }^{14} \mathrm{C}$ dated sample negates the need for stratigraphic contemporaneity.

A single $\Delta R$ value calculated from a shell/charcoal pair is reported by Petchey et al. (2009) using Turbo spp. shells from the Ta'u Hospital site, on Ta’u Island, dating from c. 500 cal BP onwards. Turbo spp. Gastropods are herbivorous with a recorded preference for calcium carbonate strata (Beesley et al., 1998:675, 768), but because Ta'u Island is the remnant of a basaltic caldera (Stearns 1944) these $\Delta R$ results are considered to be reliable.

Previously reported archaeological $\Delta R$ values from sites in Western Sāmoa (Cleghorn and Shapiro 2000, Kirch 1993) are excluded from this evaluation because the paired charcoals selected for dating were not identified as short-lived.

Kingdom of Tonga: Dating of Tonga is much more problematic because all main occupied islands are dominated by limestone (Burley 1998). Tongatapu is especially problematic because of the long residence time of water in the central Fanga Uta Lagoon which has contributed to a long-recognized hardwater effect for this island (Spennemann and Head 1998, Petchey and Clark 2011). $\Delta R$ research has been carried out at two locations; Talasiu, located within the eastern arm of the lagoon with material dated to c. $2580 \mathrm{cal} \mathrm{BP}$, and Heketa located on the ocean side of the lagoon, dated to c. 1200 cal BP (Petchey and Clark 2011).

$\Delta R$ values obtained from Tridacna sp. and Chama sp. shellfish are available from Heketa. Both taxa dislike brackish waters and are found on reef flats (Hart et al. 1998, Beesley et al. 1998:309). Turbo and Strombus ${ }^{14} \mathrm{C}$ results reported by Petchey and Clark (2011) are not included in this evaluation since both may ingest sediment while feeding. A $\Delta R$ calculated for Conus sp. is also available from Talasiu. Conus are carnivorous reef-dwelling animals (Beesley et al. 1998:852-3) and therefore should more closely reflect ocean reservoir offsets, but no comprehensive ${ }^{14} \mathrm{C}$ study has been carried out on this animal, so this value is included with caution. A large number of Anadara and Gafrarium shellfish ${ }^{14} \mathrm{C}$ dates have been obtained from the Talasiu midden. These are affected by hardwater, as indicated by depleted $\delta^{13} \mathrm{C}$ values for these shells (Petchey and Clark 2011:545), and are not considered further here. A single unpublished Pinctada sp. shell $\Delta R$-value is also available for Talasiu (Wk-48576) and has a stable isotope value that confirms a marine influence $\left(\delta^{13} \mathrm{C}=2.7 \%\right.$ ).

Fiji Islands: Two archaeological $\Delta R$ values have been published for Fiji; one from the site of Bourewa, Viti Levu (Nunn and Petchey 2013) dated to between 2866 and 2613 cal BP (95\% prob.), and a second from the site of Matanamuani on Naigani Island dated to between 3220 and 2860 cal BP (95\% prob.) (Irwin et al. 2011). Nunn and Petchey (2013:29) previously identified one short-lived terrestrial/marine pairing from Bourewa; a sample of Anadara scapha from Pit A1A paired with nutshell charcoal from adjacent Pit A1D. Although limestone was noticed in the hinterland, the $\delta^{13} \mathrm{C}(2.6 \pm 0.2 \%)$ indicates this shellfish was likely influenced by fully marine sources. Trochus - an algal grazing gastropod (Beesley et al. 1998:683) - was dated from Matanamuani. This value is considered reliable because the island is predominantly volcanic with the only limestone found on the opposite side of the island (Irwin et al. 2011).

Cook Islands: Aitutaki Island is a remnant volcanic cone (Stoddart, 1975) located in the southern Cook Islands. Initial occupation at the site of Ureia occurred c. 725-520 cal BP (68\% prob.) (Allen and Wallace 2007). Investigation of the regional reservoir offset around the Cook Islands, undertaken on material from Ureia, is reported by Petchey et al. (2009) and includes a $\Delta R$ obtained from a Pinctada sp. bivalve shell and another from Holocentridae sp. bone, an inshore fish species. Very little reservoir work has been undertaken with fishbone (see 
Petchey and Clark [2010:242] for reservoir work on Scaridae sp. fish remains from Palau), but it is thought that the ${ }^{14} \mathrm{C}$ predominantly reflects dietary protein sources which are in equilibrium with marine dissolved organic carbon.

Marquesas Islands: The Marquesas chain consists of ten main volcanic islands (Chubb 1930) at the eastern edge of the Pacific Gyre, of which Nuku Hiva Island is the largest. Reservoir offset values measured from Pinctada margarifigera and Periglypta reticulata shells from the site of Teavau'ua, Layer IV (661-518 cal BP) and Layer IIIb (543-153 cal BP, 95\% prob.) are reported in Petchey et al. (2009).

\section{$\Delta \mathrm{R}$ calculation}

$\Delta R$ values for both ${ }^{14} \mathrm{C}$ and $\mathrm{U} / \mathrm{Th}$ dated pairs (Table 1 ) have been calculated using the online tool found at http://calib.org/deltar/(Reimer and Reimer 2017), which first calibrates the terrestrial ${ }^{14} \mathrm{C}$ age with the appropriate calibration curve and then reverse-calibrates discrete points of the resulting probability density function with the marine calibration curve (Marine13; Reimer et al. 2013). Because the islands under consideration lie within the SPCZ, which merges with the ITCZ to the west (Figure 1) we have opted to use the Northern Hemisphere calibration curve (IntCal13; Reimer et al. 2013) following the recommendations of Petchey et al. (2009), though a gradient from north to south is likely (Buntgen et al. 2018) and a mixed Northern/Southern Hemisphere calibration may be more appropriate at certain time periods (cf., Marsh et al. 2018). $\Delta R$ values calculated using SHCal13 (Hogg et al. 2013) are also given in Table 1 for comparison. Calendar ages derived from U/Th measurements are similarly reverse-calibrated using the marine calibration curve. The new archaeological $\Delta R$ values are overlain on the black coral values from the east Australian coastline (Hua et al. 2015 and KomugabeDixson et al. 2016) and modern (pre-AD 1950) shell $\Delta R$ values from the South Pacific Gyre (Petchey et al. 2008, Ulm et al. 2009), both recalculated from published raw data using the online $\Delta R$ calculation tool.

\section{RESULTS}

The results are presented in Figure 2. Slightly more negative $\Delta R$ values occur between c. 500 and 750 cal BP which give way to a positive inflection starting c. 750 cal BP. The $\Delta R$ value of $98 \pm 46{ }^{14} \mathrm{C}$ years for Chama sp. shell from Heketa could theoretically be influenced by hardwater and represents the potential danger of dating shell from such locations, but this trend towards higher $\Delta R$ values is also apparent in the more extensive coral datasets. Between 2250 and 2600 cal BP results from the archaeological samples follow the same trend as the coral datasets - towards lower $\Delta R\left(\Delta R\right.$ average $=-160 \pm 11{ }^{14} \mathrm{C}$ years $\left[\chi^{2} 9: 0.05=13.99<16.92:\right.$ GSD $\left.\left.=48\right]\right)$. The combined shell/coral average $\Delta R$ for the period between 2600 and 3100 cal BP increases to $-48 \pm 10{ }^{14} \mathrm{C}$ years $\left(\chi^{2}\right.$ 10:0.05 $=33.82<16.92:$ GSD $\left.=82\right)$. The same trend is evident when the SHCal13 calibration dataset is used to calculate the $\Delta R$-value (Table 1 ). These results also suggest that there is no regional offset, with island groups from west of the salinity front (i.e., American Samoa and Tonga) found in both $\Delta R$ groupings.

\section{DISCUSSION}

Using material from archaeological contexts comparable temporal $\Delta R$ trends have been identified in the central Pacific Gyre to those measured in coral from the southeast coast of Australia (Komugabe-Dixson et al. 2016; Hua et al. 2015) (Figure 2). Komugabe-Dixson et al. (2016:977-78) argued that considerable ENSO variability between the present day and 1000 years ago was responsible for the increased influence of ${ }^{14} \mathrm{C}$-depleted water from equatorial waters and/or from the eastern boundary of the South Pacific where high $\Delta R$ values (between $355 \pm 105$ and $253 \pm 207{ }^{14} \mathrm{C}$ years) were attributed to increased influence of upwelled ${ }^{14} \mathrm{C}$-depleted water (Ortlieb et al. 2011). It is possible that black coral from further south was differentially affected during periods such as the Little Ice Age (c. 1600-1860 AD) when the EAC was weakened and increased advection of cooler sub-Antarctic waters from the Subtropical Front caused an increase in the reservoir age and $\Delta R$-value. Both shell and coral proxies have identified a significant negative shift in $\Delta R$ between c. 2600 and 2250 cal BP. Komugabe-Dixson et al. (2016) attributed this change to strong and abrupt El Niño events. To the far eastern boundary, a similar depression in $\Delta R$ occurred between 5180 and 1160 cal BP, which Ortlieb et al. (2011) also interpreted as being caused by the increased influence of subtropical water and diminished coastal upwelling processes.

The shift to more negative $\Delta R$ values between c. 2600 and 2250 cal BP occurs at a critical time in the Pacific - a time when sea-level was falling rapidly (see Dickinson 2001), interaction between different populations took place (Posth et al. 2018) and archaeological evidence points to significant cultural change that has been attributed to a developing Ancestral Polynesian Society (Kirch and Green 2001). Moreover, initial human colonization in West Polynesia followed close on the heels of falling sea-levels. To evaluate whether a regional forcing mechanism, independent of societal drivers, was primarily responsible for any societal changes (cf., Nunn and Carson 2015) it is necessary to obtain precise dates for these events. With the development of the first temporal model of changing $\Delta R$, we are only now entering a phase where ${ }^{14} \mathrm{C}$ may be able to answer these questions. Recent 
dating of the early Polynesian site of To'aga, American Sāmoa (Petchey and Kirch, in press) using a timedependent $\Delta R$ has highlighted the limitations of previous colonization models which have been put forward to account for apparent large gaps in the chronology caused by limited dating programs and widespread uncertainty in the reliability of shell dates.

An alternative to using $\Delta R$ when calibrating marine samples has recently been proposed by Butzin et al. (2017) who present simulations for spatial and temporal variability in the global marine reservoir age calculated from ocean circulation and temporally specific climate models. A regional marine reservoir age curve for the central South Pacific Gyre has subsequently been produced by Alves et al. (2019, fig 10c). This model displays a similar pattern in reservoir age to the archaeological samples from the central South Pacific Gyre and black coral from the South Tasman Sea but does not reproduce the very low values recorded in these datasets. This contradicts the findings of Alves et al. (2019:132-133) who noted that modeled data worked best in open-ocean areas of the Pacific, as evidenced by similarity to measured coral values recorded by Burr et al. (2015) for the Solomon Islands. This disjunction with the black coral/archaeological pairs could be caused by poor resolution or inaccurate inclusion of carbon cycle and ocean circulation changes in the reservoir age model (cf., Alves et al. 2019:136). Moreover, the Burr et al. (2015) dataset has only 6 measured values for the time period of interest here and is found at the end of the gyre where $\Delta \mathrm{R}$ variability is likely to be masked (Petchey et al. 2008b). This is clearly something to investigate further.

\section{CONCLUSION}

Evidence obtained from archaeological materials demonstrate that between 2600 and 2250 cal BP the marine ${ }^{14} \mathrm{C}$ reservoir offset $(\Delta R)$ across the central South Pacific Gyre was lower than the present. This observation matches coral U/Th, ${ }^{14} \mathrm{C}$ paired data collected from the east coast of Australia. This central South Pacific Gyre $\Delta R$ dataset fills a gap in ocean circulation and climate reconstructions between 3500 and 1000 cal BP - a key period that incorporates initial human settlement across the region and the subsequent development of Polynesian culture. The inclusion of shell $\Delta R$ values into extant datasets has been made possible because of advances in our understanding of ${ }^{14} \mathrm{C}$ uptake by shellfish, which has enabled the recognition of marine versus estuarine influences and the exclusion of shells where the age has been affected by depleted ${ }^{14} \mathrm{C}$ from hardwater. To develop a more accurate and precise model of human colonization across this region it is essential that more $\Delta R$ values are obtained, especially for the period post-2600 cal BP.

\section{ACKNOWLDGEMENTS}

This paper developed from an observation that reservoir ages calculated on coral from archaeological deposits in American Samoa did not conform to established geographical $\Delta R$ divisions for the region. This single observation enabled me to revisit the many marine ${ }^{14} \mathrm{C}$ reservoir projects undertaken over the last 15 years and provide context to information that appeared muddled. Special thanks go to all the Pacific archaeologists that have provided shell and charcoal samples for this research.

Figure 1: Map of the Pacific Ocean showing major circulation patterns and sites mentioned in the text. The dashed line shows the salinity front on the eastern edge of the Western Pacific Warm Pool. Surface currents: SEC = South Equatorial Current; EAC = East Australian Current; NGCC = New Guinea Coastal Current; ACC = Antarctic Circumpolar Current. + = Black coral sampling locations (from KomugabeDixson et al. 2016).

Figure 2. Change in $\Delta R$ across the South Pacific over the last 3500 years. Squares = archaeological $\Delta R$ values mentioned in text. Trendline based on a 4-point moving average.

\section{REFERENCES}

Allen, M.S., Wallace R., 2007. New evidence from the East Polynesian gateway: Substantive and methodological results from Aitutaki, southern Cook Islands. Radiocarbon 49 (3):1-17.

Alves, E.Q., Macario, K.D., Urrutia, F.P., Cardoso, R.P., Ramsey, C.B., 2019. Accounting for the marine reservoir effect in radiocarbon calibration. Quaternary Science Reviews 209:129-138.

Beesley, P.L., Ross G.J.B., Wells A. (Eds.), 1998. Mollusca: The Southern Synthesis. Fauna of Australia vol. 5. CSIRO Publishing, Melbourne (1234 pp.). 
Büntgen, U., Wacker L., Diego Galván, J., Arnold S., Arseneault D., Baillie M., Beer J., Bernabei M, Bleicher N., Boswijk G., Bräuning A, Carrer M., Ljungqvist F.C., Cherubini P., Christ M., Christie D.A., Clark P.W., Cook E.R., D’Arrigo R., Davi N., Eggertsson O., Esper J., Fowler A.M., Gedalof Z., Gennaretti F., Grießinger J., Grissino-Mayer H., Grudd H., Gunnarson B.E., Hantemirov R., Herzig F., Hessl A., Heussner K-U., Jull A.J.T., Kukarskih V., Kirdyanov A., Koláŕ T., Krusic P.J., Kync T., Lara A., LeQuesne C., Linderholm H.W., Loader N.J., Luckman B., Miyake F., Myglan V.S., Nicolussi K., Oppenheimer C., Palmer J., Panyushkina I., Pederson N., Rybníček M., Schweingruber F.H., Seim A., Sigl M, Churakova (Sidorova) O., Speer J.H., Synal H-A., Tegel W., Treydte K., Villalba R., Wiles G., Wilson R. Winship L.J., Wunder J., Yang B., Young G.H.F., 2018. Tree rings reveal globally coherent signature of cosmogenic radiocarbon events in 774 and 993 CE. Nature Communications 9(3605): doi: 10.1038/s41467-018-06036-0.

Burley, D.V., 1998. Tongan archaeology and the Tongan past, 2850-150 B.P. Journal of World Prehistory, 12(3):337-392.

Burr, G.S., Beck J.W., Corrège T., Cabioch G., Taylor F.W., Donahue D.J., 2009. Modern and Pleistocene reservoir ages inferred from South Pacific corals. Radiocarbon 51:319-335.

Burr, G., Haynes C., Shen C., Taylor F., Chang Y., Beck J., Nguyen V., Zhou W., 2015. Temporal variations of radiocarbon reservoir ages in the south Pacific Ocean during the Holocene. Radiocarbon 57(4):507-515.

Butzin, M., Koehler, P., Lohmann, G., 2017. Marine radiocarbon reservoir age simulations for the past 50,000 years. Geophysical Research Letters 44(16):8473-8480.

Chubb, L.J., 1930. Geology of the Marquesas Islands. Bernice P. Bishop Museum Bulletin 68, Honolulu, Hawai’i.

Clark, J., Quintus S., Weisler M., St Pierre E., Nothdurft L., Feng Y., Hua Q., 2016a. Marine reservoir correction for American Samoa using U-series and AMS dated corals. Radiocarbon 58(4):doi:10.1017/RDC.2016.53.

Clark, J., Quintus S., Weisler M., St Pierre E., Nothdurft L., Feng Y., 2016b. Refining the chronology for west Polynesian colonization: New data from the Samoan archipelago. Journal of Archaeological Science: Reports 6:266-274.

Cleghorn, P., Shapiro, W., 2000. Archaeological data recovery report for the proposed Ta'u road reconstruction, at Faga and Fitiuta, Ta‘u Island, Manu‘a, American Samoa. Prepared for U.S. Army Corp of Engineers. Pacific Legacy, Inc.

Dickinson, W.R., 2001. Paleoshoreline record of relative Holocene sea levels on Pacific islands. Earth-Science Reviews 55:191-234.

Fairbanks, R.G., Mortlock, R.A., Chiu, T.-C., Cao, L., Kaplan, A., Guilderson, T.P., Fairbanks, T.W., Bloom, A.L., Grootes, P.M., Nadeau, M.-J., 2005. Radiocarbon calibration curve spanning 0 to 50,000 years BP based on paired ${ }^{230} \mathrm{Th} /{ }^{234} \mathrm{U} /{ }^{238} \mathrm{U}$ and ${ }^{14} \mathrm{C}$ dates on pristine corals. Quaternary Science Reviews, 24:1781-1796.

Hart, A.M., Bell, J.D., Foyle, T.P., 1998. Growth and survival of the giant clams, Tridacna derasa, T. maxima and T. crocea, at village farms in the Solomon Islands. Aquaculture 165, 203e220.

Hogg, A.G., Hua, Q., Blackwell, P.G., Niu, M., Buck, C.E., Guilderson, T.P., Heaton, T.J., Palmer, J.G., Reimer, P.J., Reimer, R.W., Turney, C.S.M., Zimmerman, S.R.H., 2013. ShCal13 Southern Hemisphere calibration, 050,000 years cal BP. Radiocarbon 55(4):1889-1903.

Hua, Q., Webb G.E., Zhao J.X., Nothdurft L., Lybolt M., Price G.J., Opdyke B.N., 2015. Large variations in the Holocene marine radiocarbon reservoir effect reflect ocean circulation and climate changes. Earth and Planetary Science Letters 422:33-44.

Irwin, G., Worthy T.H., Best S., Hawkins S., Carpenter J., Matararaba S., 2011. Further investigations at the Naigani Lapita site (VL 21/5), Fiji: excavation, radiocarbon dating and palaeofaunal extinction. Journal of Pacific Archaeology 2:66-78. 
Jones, M., Petchey F., Green R., Sheppard P., Phelan M., 2007. The marine $\Delta R$ for Nenumbo: a case study in calculating reservoir offsets from paired sample data. Radiocarbon 49(1):95-102.

Kirch, P.V. 1993. Radiocarbon chronology of the To’aga Site. In: Kirch P.V., Hunt T.L., editors. The To’aga Site: Three Millennia of Polynesian Occupation in the Manu'a Islands, American Samoa. Berkeley: Contributions of the University of California Archaeological Research Facility No. 51. p 85-92.

Kirch, P., 1997. The Lapita Peoples: Ancestors of the Oceanic World, Oxford: Blackwell.

Kirch, P., Green R., 2001. Hawaiki: Ancestral Polynesia, Cambridge: Cambridge University Press.

Komugabe-Dixson, A., Fallon S., Eggins S., Thresher R., 2016. Radiocarbon evidence for mid-late Holocene changes in southwest Pacific Ocean circulation. Paleoceanography, 31:971-985, doi:10.1002/2016PA002929.

Macario, K.D., Souza R.C.C.L., Aguilera O.A., Carvalho C., Oliveira F.M., Alves E.Q., Chanca I.S., Silva E.P., Douka K., Decco J., Trindade D.C., Marques A.N., Anjos R.M., Pamplona F.C., 2015. Marine reservoir effect on the Southeastern coast of Brazil: Results from the Tarioba shellmound paired samples. Journal of Environmental Radioactivity 143:14-19.

Marsh, E.J, Bruno, M.C, Fritz, S.C., Baker, P., Capriles, J.M., Hastorf, C.A., 2018. Intcal, SHCal, or a mixed curve? Choosing a ${ }^{14} \mathrm{C}$ calibration curve for archaeological and paleoenvironmental records from tropical South America. Radiocarbon, doi:10.1017/RDC.2018.16.

McConnaughey, T.A., Burdett J., Whelan J.F., Paull C.K., 1997. Carbon isotopes in biological carbonates: respiration and photosynthesis. Geochimica et Cosmochimica Acta 61:611-622.

Nunn, P.D., Carson M.T., 2015. Sea-level fall implicated in profound societal change about 2570 cal yr BP (620 BC) in western Pacific island groups. Geography and Environment 2:17-32. https://doi.org/10.1002/geo2.3.

Nunn, P.D., Petchey F. 2013. Bayesian re-evaluation of Lapita settlement in Fiji: radiocarbon analysis of the Lapita settlement at Bourewa and nearby sites on the Rove Peninsula, Viti Levu Island. Journal of Pacific Archaeology 4(2):21-34.

Ortlieb, L., Vargas G., Saliège J.-F., 2011. Marine radiocarbon reservoir effect along the northern Chile-southern Peru coast $\left(14-24^{\circ} \mathrm{S}\right)$ throughout the Holocene, Quaternary Research 75:91-103, doi:10.1016/j.yqres.2010.07.018.

Paterne, M., Ayliffe, L.K., Arnold, M., Cabioch, G., Tisnerat-Laborde, N., Hatté, C., Dou-ville, E., Bard, E., 2004. Paired ${ }^{14} \mathrm{C}$ and ${ }^{230} \mathrm{Th} / \mathrm{U}$ dating of surface corals from the Marquesas and Vanuatu (sub-equatorial Pacific) in the 3000 to 15,000 cal yr interval. Radiocarbon 46:551-566.

Petchey, F., 2009. Dating marine shell in Oceania: Issues and prospects. In: A. Fairbairn, S. O'Connor \& B. Marwick (Eds), New Directions in Archaeological Science. (Pp. 157-172) ANU E Press.

Petchey, F., Clark G. 2010. A $\Delta R$ for the Palau Islands: An evaluation of extant and new $\Delta R$ values and their application to archaeological deposits at Ulong. Journal of Island Archaeology, 5:236-252. doi:10.1080/15564890903155935.

Petchey, F., Clark G., 2011. Tongatapu hardwater: investigation into the ${ }^{14} \mathrm{C}$ marine reservoir offset in lagoon, reef and open ocean environments of a limestone island. Quaternary Geochronology 6:539-554.

Petchey, F., Kirch P.V., Under review. Re-dating of the To'aga site (Ofu Island, Manu'a) and a Revised Chronology for the Lapita to Polynesian Plainware Transition in Tonga and Samoa. PLos One. Open Access version at http://biorxiv.org/cgi/content/short/532648v1

Petchey, F., Allen M.S., Addison D.J., Anderson A., 2009. Stability in the South Pacific marine ${ }^{14} \mathrm{C}$ reservoir over the last 750 years. Evidence from American Samoa, the southern Cook Islands and the Marquesas. Journal of Archaeological Science 36(10):2234-43. 
Petchey, F., Anderson A., Hogg A., Zondervan A., 2008a. The marine reservoir effect in the Southern Ocean: an evaluation of extant and new $\Delta R$ values and their application to archaeological chronologies. Journal of the Royal Society of New Zealand 38 (4):243-262.

Petchey, F., Anderson A., Zondervan A., Ulm S., Hogg A., 2008b. New marine $\Delta R$ values for the South Pacific subtropical gyre region. Radiocarbon 50 (3):373-397.

Petchey, F., Clark G., Lindeman I., O’Day P., Southon J., Dabell K., Winter O. 2018. Shellfish isotopic insight into changing sea-level and associated impact on the first settlers of the Mariana Archipelago. Quaternary Geochronology. 10.1016/j.quageo.2018.10.002.

Petchey, F., Phelan M., \& White P., 2004. New $\Delta R$ values for the southwest Pacific Ocean. Radiocarbon 46(2):1005-1014.

Petchey, F., Ulm S., David B., McNiven I.J., Asmussen B., Tomkins H., Richards T., Rowe C., Leavesley M., Mandui H., Stanisic J., 2012. Radiocarbon marine reservoir variability in herbivores and deposit-feeding gastropods from an open coastline, Papua New Guinea. Radiocarbon 54 (3-4), 1-11.

Petchey, F., Ulm S., David B., McNiven I.J., Asmussen B., Tomkins H., Dolby N., Aplin K., Richards T., Rowe C., Leavesley M., Mandui H., 2013. High-resolution radiocarbon dating of marine materials in archaeological contexts: radiocarbon marine reservoir variability between Anadara, Gafrarium, Batissa, Polymesoda and Echinoidea at Caution Bay, Southern coastal Papua New Guinea. Archaeological and Anthological Science 5(1):69-80.

Petchey, F., Spriggs, M., Bedford, S., Valentin, F., 2015. The chronology of occupation at Teouma, Vanuatu: Use of a modified chronometric hygiene protocol and Bayesian modelling to evaluate midden remains. Journal of Archaeological Science: Reports 4:95-105. doi:10.1016/j.jasrep.2015.08.024.

Phelan, M.B., 1999. A $\Delta R$ correction value for Sāmoa from known-age marine shells. Radiocarbon 41(1):99-101.

Posth, C., Nägele K., Colleran H., Valentin F., Bedford S., Kami K.W., Shing R., Buckley H., Kinaston R., Walworth M., Clark G.R., Reepmeyer C., Flexner J., Maric T., Moser J., Gresky J., Kiko L., Robson K.J., Auckland K., Oppenheimer S.J., Hill A.V.S., Mentzer A.J., Zech J., Petchey F., Roberts P., Jeong C., Gray R.D., Krause J., Powell A., 2018. Language continuity despite population replacement in Remote Oceania. Nature Ecology and Evolution. doi:10.1038/s41559-018-0498-2.

Ortlieb, L., Vargas G., Saliège J.-F., 2011. Marine radiocarbon reservoir effect along the northern Chile-southern Peru coast (14-24॰S) throughout the Holocene. Quaternary Research 75:91-103.

Reimer, P.J., Bard E., Bayliss A., Beck J.W., Blackwell P.G., Bronk Ramsey C., Buck C.E., Cheng H., Edwards R.L., Friedrich M., Grootes P.M., Guilderson T.P., Haflidason H., Hajdas I., Hatte C., Heaton T.J., Hoffmann D.L., Hogg A.G., Hughen K.A., Kaiser K.F., Kromer B., Manning S.W., Niu M., Reimer R.W., Richards D.A., Scott E.M., Southon J.R., Staff R.A., Turney C.S.M., van der Plicht J., 2013. IntCal13 and Marine13 radiocarbon age calibration curves, 0-50000 years cal BP. Radiocarbon 55 (4):1869-1887.

Reimer, R.W., Reimer P.J., 2017. An online application for $\Delta R$ calculation. Radiocarbon 59 (5):1623-1627.

Rougerie F, Wauty B. 1993. L’océanographie du Pacifique Central Sud. In: Atlas de Polynésie Française. ORSTOM editions. p 20-1. In French.

Spennemann, D.H.R., Head M.J., 1998. Tongan pottery chronology, ${ }^{14} \mathrm{C}$ dates and the hardwater effect. Quaternary Geochronology 17:1047-1056.

Sikes, E.L., Samson C.R., Guilderson T.P., Howard W.R., 2000. Old radiocarbon ages in the southwest Pacific Ocean during the last glacial period and deglaciation. Nature 405:555-559.

Stearns, H., 1944. "Geology of the Sāmoan Islands". Bulletin of the Geological Society of America. 55 (November): 1312-1313. doi:10.1130/gsab-55-1279. 
Stoddart, D.R., 1975. Scientific studies in the southern Cook Islands: Background and bibliography. In: Stoddart, D.R., Gibbs, P.E. (Eds.), Almost-Atoll of Aitutki: reef Studies in the Cook Islands, South Pacific. Atoll of Aitutaki: Reef Studies in the Cook Islands, South Pacific. Atoll Research Bulletin 190. Smithsonian Institution, Washington, D.C, pp. 1-30.

Stuiver, M., Pearson G.W., Braziunas T., 1986. Radiocarbon age calibration of marine samples back to 9000 cal yr BP. Radiocarbon 28(2B):980-1021.

Toggweiler, J.R., Dixon K., Broecker W.S., 1991. The Peru upwelling and the ventilation of the South Pacific thermocline. Journal of Geophysical Research 96:20,467-20,497, doi:10.1029/91JC02063.

Ulm, S., Petchey F., Ross A., 2009. Marine reservoir corrections for Moreton Bay, Australia. Archaeology in Oceania 44:160-168.

Yu, K., Hua Q., Zhao J.-X., Hodge E., Fink D., Barbetti M., 2010. Holocene marine ${ }^{14} \mathrm{C}$ reservoir age variability: evidence from ${ }^{230}$ Th-dated corals from South China Sea. Paleoceanography 25, PA3205. http://dx.doi.org/10.1029/2009PA001831. 
Table 1: Archaeological $\Delta \mathrm{R}$ terrestrial/marine pairs from the central South Pacific Gyre.

\begin{tabular}{|c|c|c|c|c|c|c|c|c|c|c|}
\hline & \multicolumn{3}{|c|}{ Terrestrial Data } & \multicolumn{5}{|c|}{ Marine Data } & \multicolumn{2}{|c|}{$\Delta R\left({ }^{14} \mathrm{C}\right.$ years $)$} \\
\hline & $\begin{array}{l}\text { Calendar age } \\
\text { Mean } \\
(68 \% \text { prob, } \\
\text { range)* }\end{array}$ & $\begin{array}{l}\text { Sample ID } \\
\text { (age/CRA) } \\
\text { Material }\end{array}$ & Site & ${ }^{14}$ C Lab Code & $\begin{array}{l}\text { Conventio } \\
\text { nal } \\
\text { Radiocarb } \\
\text { on Age } \pm \\
\text { error (BP) } \\
\end{array}$ & $\begin{array}{l}\delta^{13} \mathrm{C} \\
(\%)\end{array}$ & $\begin{array}{l}\text { Classific } \\
\text { ation\# }\end{array}$ & Material & $\begin{array}{l}\Delta \mathrm{R} \\
\text { Intcal13 } \\
(\mathbf{6 8 \%} \% \\
\text { conf.) } \\
\end{array}$ & $\begin{array}{l}\Delta \mathrm{R} \\
\text { SHCal13 } \\
(68 \% \\
\text { conf.) }\end{array}$ \\
\hline \multirow{4}{*}{$\begin{array}{l}\text { AMERICAN } \\
\text { SAMOA }\end{array}$} & 2468 & $\begin{array}{l}2014-16 \\
(\mathrm{U} / \mathrm{Th}=2470 \pm 8)\end{array}$ & $\begin{array}{l}\text { Va'oto (AS-13-13), Layer } \\
\text { IVb, Ofu Island }\end{array}$ & OZT-063 & $2566 \pm 27$ & -0.2 & $\mathrm{M} / \mathrm{V}$ & Coral: Acropora sp. abrader & \multicolumn{2}{|l|}{$-194 \pm 28$} \\
\hline & 2375 & $\begin{array}{l}2014-22 \\
(\mathrm{U} / \mathrm{Th}=2375 \pm 11)\end{array}$ & $\begin{array}{l}\text { Va'oto (AS-13-13), Layer VI, } \\
\text { Ofu Island }\end{array}$ & OZT-064 & $2559 \pm 24$ & -0.3 & $\mathrm{M} / \mathrm{V}$ & $\begin{array}{ll}\text { Coral: Acropora sp. } \\
\text { unmodified }\end{array}$ & \multicolumn{2}{|l|}{$-149 \pm 25$} \\
\hline & 2796 & $\begin{array}{l}2014-15 \\
(\mathrm{U} / \mathrm{Th}=2796 \pm 9)\end{array}$ & $\begin{array}{l}\text { Coconut Grove (AS-13-37), } \\
\text { Layer III, Ofu Island }\end{array}$ & OZT-062 & $2984 \pm 16$ & 0.4 & $\mathrm{M} / \mathrm{V}$ & $\begin{array}{l}\text { Coral: Acropora sp. } \\
\text { unmodified }\end{array}$ & \multicolumn{2}{|l|}{$-60 \pm 17$} \\
\hline & $\begin{array}{l}600 \\
(650-550) \\
\text { cal BP } \\
\end{array}$ & $\begin{array}{l}\text { Wk-21993 } \\
\text { Cocos nucifera charcoal } \\
(611 \pm 30)\end{array}$ & $\begin{array}{l}\text { Ta'u Hospital, Layer 5, Ta'u } \\
\text { Island }\end{array}$ & Wk-21994 & $1020 \pm 30$ & 2.8 & $\mathrm{G} / \mathrm{V}$ & Shell: Turbo crassus & $-18 \pm 50$ & $26 \pm 44$ \\
\hline \multirow{6}{*}{ TONGA } & \multirow{2}{*}{$\begin{array}{l}730 \\
(760-690) \\
\text { cal BP }\end{array}$} & \multirow{2}{*}{$\begin{array}{l}\text { Wk-21833 } \\
(821 \pm 30)\end{array}$} & \multirow{2}{*}{$\begin{array}{l}\text { Heketa (HEK), 100-110cm, } \\
\text { Tongatapu Island }\end{array}$} & Wk-21953 & $1175 \pm 30$ & 2.8 & $\mathrm{M} / \mathrm{L}$ & Shell: Tridacna sp. Juvenile & $-22 \pm 42$ & $9 \pm 38$ \\
\hline & & & & Wk-21955 & $1296 \pm 35$ & 3.1 & $\mathrm{M} / \mathrm{L}$ & Shell: Chama sp. & $98 \pm 46$ & $130 \pm 42$ \\
\hline & \multirow{4}{*}{$\begin{array}{l}2590 \\
(2710-2490) \\
\text { cal BP }\end{array}$} & \multirow{4}{*}{$\begin{array}{l}\text { Wk-23234 and Wk-28235 } \\
\text { (Pooled result }=2492 \pm 22 \text { ) } \\
\text { Cocos nucifera charcoal }\end{array}$} & \multirow{4}{*}{$\begin{array}{l}\text { Talasiu (TAL), } 55-80 \mathrm{~cm} \text {, } \\
\text { Tongatapu Island }\end{array}$} & Wk-22999 & $2767 \pm 37$ & 2.2 & $\mathrm{M} / \mathrm{L}$ & Shell: Tridacna sp. & $-92 \pm 66$ & $-42 \pm 72$ \\
\hline & & & & Wk-23000 & $2726 \pm 30$ & 2.8 & $\mathrm{M} / \mathrm{L}$ & Shell: Tridacna sp. & $-132 \pm 63$ & $-84 \pm 70$ \\
\hline & & & & Wk-23001 & $2682 \pm 30$ & 3.5 & $\mathrm{G} / \mathrm{L}$ & Shell: Conus sp. & $-176 \pm 63$ & $-128 \pm 70$ \\
\hline & & & & Wk-48576 & $2753 \pm 17$ & 2.7 & $\mathrm{M} / \mathrm{L}$ & Shell: Pinctada sp. & $-100 \pm 72$ & $-56 \pm 72$ \\
\hline \multirow{3}{*}{ MARQUESAS } & \multirow{2}{*}{$\begin{array}{l}670 \\
(690-660) \\
\text { cal BP }\end{array}$} & \multirow{2}{*}{$\begin{array}{l}\text { Wk-20135 and } 20134 \\
\text { (Pooled result }=725 \pm 20 \text { ) } \\
\text { Cocos nucifera charcoal }\end{array}$} & \multirow{2}{*}{$\begin{array}{l}\text { Teavau'ua (AHO-1), Layer } \\
\text { IV, Nuku Hiva, Marquesas }\end{array}$} & Wk-13833 & $1169 \pm 36$ & 2.2 & $\mathrm{M} / \mathrm{V}$ & $\begin{array}{ll}\text { Shell: } & \text { Pinctada } \\
\text { margaritifera } & \\
\end{array}$ & $36 \pm 38$ & $76 \pm 42$ \\
\hline & & & & Wk-20133 & $1172 \pm 30$ & 1.7 & $\mathrm{M} / \mathrm{V}$ & Shell: Periglypta reticulata & $39 \pm 32$ & $80 \pm 38$ \\
\hline & $\begin{array}{l}370 \\
(430-300) \\
\text { cal BP } \\
\end{array}$ & $\begin{array}{l}\text { Wk-19116 } \\
\text { (296 } \pm 34) \\
\text { Thespesia populnea charcoal }\end{array}$ & $\begin{array}{l}\text { Teavau'ua (AHO-1), Layer } \\
\text { IIIb, Nuku Hiva }\end{array}$ & Wk-20132 & $710 \pm 37$ & 1.9 & $\mathrm{M} / \mathrm{V}$ & Shell: Periglypta reticulata & $-26 \pm 56$ & $8 \pm 58$ \\
\hline \multirow{2}{*}{$\begin{array}{l}\text { COOK } \\
\text { ISLANDS }\end{array}$} & \multirow{2}{*}{$\begin{array}{l}660 \\
(680-660) \\
\text { cal BP }\end{array}$} & \multirow{2}{*}{$\begin{array}{l}\text { Wk-18402 and Wk-20568 } \\
\text { (Pooled result }=705 \pm 21 \text { ) } \\
\text { Thespesia populnea and } \\
\text { Cocos nucifera charcoal }\end{array}$} & \multirow{2}{*}{$\begin{array}{l}\text { Ureia, (ATI-10), Zone G, } \\
\text { Aitutaku Island }\end{array}$} & Wk-20130 & $1093 \pm 31$ & 2.5 & $\mathrm{M} / \mathrm{V}$ & Shell: Pinctada sp. & $-28 \pm 34$ & $16 \pm 40$ \\
\hline & & & & Wk-23091 & $1074 \pm 30$ & -10.6 & - & Fish: Holocentridae sp. & $-48 \pm 32$ & $-2 \pm 40$ \\
\hline \multirow{2}{*}{ FIJI } & $\begin{array}{l}2820 \\
(2860-2780) \\
\text { cal BP } \\
\end{array}$ & $\begin{array}{l}\text { Wk-23118 } \\
(2727 \pm 35) \\
\text { Nutshell charcoal }\end{array}$ & $\begin{array}{l}\begin{array}{l}\text { Bourewa, } \\
\text { A1A/A1D }\end{array} \\
\end{array}$ & Wk-23067 & $2969 \pm 39$ & 2.6 & $\mathrm{M} / \mathrm{L}$ & Shell: Anadara scapha & $-95 \pm 49$ & $-65 \pm 50$ \\
\hline & $\begin{array}{l}2980 \\
(3060-2880) \\
\text { cal BP }\end{array}$ & $\begin{array}{l}\text { Wk-10294 } \\
(2852 \pm 57) \\
\text { Grass, reed or palm frond }\end{array}$ & $\begin{array}{l}\text { Naigani (VL 21/5), Sq A5, } \\
\text { oven }\end{array}$ & Wk-10296 & $3110 \pm 52$ & 3.0 & G/V & Shell: Trochus sp. & $-72 \pm 80$ & $-30 \pm 80$ \\
\hline
\end{tabular}

* Radiocarbon dates calibrated using Intcal13 (Reimer et al. 2013) in OxCal version 4.3 .2 (https://c14.arch.ox.ac.uk/).

\# M = Marine environmental influence; $\mathrm{G}=$ gastropod; $\mathrm{V}$ = Volcanic environment; $\mathrm{L}$ = Limestone environment. 
Lab prefixes: OZT - ANSTO, Australian Nuclear Science and Technology Organisation; Wk = University of Waikato. 